\title{
„Фað er ekki til ein uppskrift“ Fyrsta ár flóttabarna í leikskólum í premur sveitarfélögum á Íslandi
}

\author{
Hanna Ragnarsdóttir
}
Abstract
- Um höfund
About the author
- Heimildir

Árið 2016 kom hópur sýrlenskra kvótaflóttafjölskyldna til Íslands frá Líbanon og settist aðí premur sveitarfélögum (Stjórnarráð Íslands, 2019). Markmið rannsóknarinnar, sem hófst síðla árs 2016 og er langtímarannsókn, eru að athuga reynslu flóttabarna og foreldra peirra af leik- og grunnskólastarfi og frístundastarfi; og að athuga reynslu stjórnenda og kennara í skólum og frístundaheimilum af móttöku barnanna, skipulagi náms og samstarfi við foreldrana. Í greininni er fjallað um pær niðurstöður rannsóknarinnar er snúa að reynslu starfsfólks leikskóla af móttöku og starfi með flóttabörnum úr hópnum og foreldrum peirra fyrsta árið. Fræðilegur grunnur rannsóknarinnar er í gagnrýnum sjónarhornum á menntun og skólastarf (Banks, 2013; May og Sleeter, 2010; Nieto, 2010) og fjöltyngismenntun til félagslegs réttlætis (Chumak-Horbatsch, 2012; Cummins, 2004; Skutnabb-Kangas, Phillipson, Mohanty og Panda, 2009). Gagnrýnin sjónarhorn á menntun og skólastarf og fjöltyngismenntun til félagslegs réttlætis eru mikilvæg tæki til að varpa gagnrýnu ljósi á reynslu barna af menntun og leggja til umbætur. Gagna var aflað með hálfstöðluðum viðtölum við starfsfólk sex leikskóla. Niðurstöður benda til pess að börnunum vegni vel í leikskólunum og samstarf við foreldra gangi almennt vel, ekki síst vegna góðs undirbúnings fyrir komu flóttabarnanna. Рað eru pó ærin verkefni sem leikskólarnir standa frammi fyrir, og snerta m.a. ólík tungumál og menningu.

Efnisorð: Flóttabörn, leikskólar, fjölskyldur, áskoranir.

\section{Inngangur}

Fólk flytur til Íslands af ólíkum ástæðum, en hluti peirra sem flytja til landsins er flóttafólk og hefur beim fjölgað undanfarin ár. Á síðustu áratugum (1956-2018) hafa alls 704 kvótaflóttamenn sest að hér á landi (Stjórnarrád Íslands, 2019). Síðustu fjögur ár hefur Ísland tekið á móti flóttafólki frá Sýrlandi sem sest hefur að í nokkrum sveitarfélögum.

Rannsóknin fjallar um ellefu fjölskyldur kvótaflóttafólks frá Sýrlandi sem komu til Íslands árið 2016 og settust að í premur sveitarfélögum. Markmið rannsóknarinnar, sem hófst síðla árs 2016 og er langtímarannsókn, eru að athuga reynslu flóttabarna og foreldra peirra af leik- og grunnskólastarfi og frístundastarfi; og að athuga reynslu stjórnenda og kennara í skólum og frístundaheimilum af móttöku barnanna, skipulagi náms og samstarfi við foreldrana. Í greininni er fjallað um reynslu starfsfólks sex leikskóla í sveitarfélögunum premur af móttöku og starfi með sjö flóttabörnum úr hópnum og foreldrum peirra fyrsta árið. 


\section{Móttaka kvótaflóttafólks á Íslandi}

Degar fjölskyldur kvótaflóttafólks koma til Íslands fer af stað ferli um móttöku peirra og stuðning sem hefur verið skipulagt á löngum tíma í samstarfi Velferðarráðuneytisins, Rauða kross Íslands og sveitarfélaga (Stjórnarráð Íslands, 2013). Hver fjölskylda fær 3-5 stuðningsfjölskyldur, en hlutverk stuðningsfjölskyldna er einkum að styðja flóttafólkið félagslega og við aðlögun að samfélaginu. Fjölskyldunum eru útvegaðar íbúðir hjá sveitarfélögunum sem taka á móti peim. Samningarnir við sveitarfélögin eru að jafnaði til eins árs. Námskeið eru skipulögð fyrir fullorðna einstaklinga 1 hópum flóttafólks, annars vegar íslenskunámskeið og hins vegar námskeið um menningu og samfélag. Börn kvótaflóttamanna byrja flest í skólum um leið og fyrstu heilbrigðisskoðun lýkur. Teymi skipuleggja og undirbúa komu flóttafólksins í hverju sveitarfélagi. Dau geta verið ólík eftir sveitarfélögum, en í peim taka pátt m.a. fulltrúar Rauða krossins, sveitarfélaga, skóla, félagspjónustu og heilbrigðiskerfisins. Leiðbeinandi reglur fyrir sveitarfélög um móttökupjónustu og aðstoð við félagslega pátttöku flóttafólks (Velferðarráðuneytið, 2014) kveða á um framkvæmd pjónustu við flóttafólkið, m.a. margvíslega félagslega og fjárhagslega aðstoð, íslenskukennslu og skólagöngu barna.

Sveitarfélög sem taka á móti flóttafólki skipuleggja fræðslu fyrir starfsfólk sitt. Skólaskrifstofur bjóða starfsfólki skóla á fundi og halda námskeið til að undirbúa komu flóttabarnanna. Á námskeiðunum er m.a. fjallað um áfallastreitu og reynslu flóttabarna með almennum hætti. Að kennslu á námskeiðunum koma m.a. verkefnastjórar frá Rauða krossinum í málefnum flóttafólks og sálfræðingar.

\section{Fræðilegur bakgrunnur}

Fræðilegur bakgrunnur rannsóknarinnar er í gagnrýnum sjónarhornum (e. critical theories) á menntun og skólastarf (Banks, 2013; May og Sleeter, 2010; Nieto, 2010) par sem réttindi minnihlutahópa til menntunar eru í forgrunni, svo og vinna gegn ójöfnuði. Sjónarhorn fjöltyngismenntunar til félagslegs réttlætis (Chumak-Horbatsch, 2012; Cummins, 2004; SkutnabbKangas, Phillipson, Mohanty og Panda, 2009) er einnig lagt til grundvallar í rannsókninni. Gagnrýnin sjónarhorn á menntun og skólastarf og fjöltyngismenntun (e. multilingual education) til félagslegs réttlætis eru mikilvæg tæki til að varpa gagnrýnu ljósi á reynslu barna af menntun og leggja til umbætur.

Siraj-Blatchford (2006) bendir á að börn geti upplifað mismunun á grundvelli uppruna, tungumáls, kyns og stéttar pó að slíkt sé ekki ætlunin í skólastarfinu. Hún telur mikilvægt að öll börn læri virðingu fyrir fjölbreytileikanum og að komið sé í veg fyrir innbyggða mismunun í menntastofnunum. Robinson og Díaz (2006) hafa á sama hátt lagt áherslu á félagslegt réttlæeti í menntun fyrir öll börn og að pað feli m.a. í sér markvisst samstarf við foreldra peirra. Mikilvægt sé að virkja foreldra til pátttöku, ekki síst pá foreldra sem eru í jaðarstöðu. Dórdís Dórðardóttir (2016) heldur fram í grein sinni um jafnrétti í leikskólum að par geti, eins og annars staðar í samfélaginu, myndast menningartengdar hindranir pó að erfitt geti reynst að greina pær í erli dagsins. Gera purfi greinarmun á mismunun utan valdsviðs leikskólanna og menningarbundinni mismunun sem vinna má gegn innan leikskólanna.

Cummins $(2001,2004)$ telur, að til að hægt sé að próa námsrými jöfnuðar fyrir fjöltyngda nemendahópa, purfi skólar að leggja áherslu á aðferðir sem byggja á reynslu og bekkingu nemenda, m.a. í tungumálum. Chumak-Horbatsch (2012) heldur pví fram að kennsluaðferðir sem leggja áherslu á eitt tungumál hafi neikvæðar afleiðingar fyrir fjöltyngda nemendahópa og leiði til pöggunar fjöltyngdra nemenda. Skilaboð til peirra séu að móðurmál peirra séu bönnuð og að pekking peirra á tungumálum sé minna virði en hinna nemendanna. Dví purfi að byggja markvisst á tungumálum allra barna í skólastarfi. 
Niðurstöður rannsókna hafa sýnt fram á mikilvægi menntunar fyrir félagslegan og tilfinningalegan bata flóttabarna og bent til pess að skólaumhverfi hafi mikilvægu hlutverki að gegna við að auðvelda félagsmótun og aðlögun flóttabarna að nýrri menningu (Eisenbruch, 1988; Hones og Cha, 1999). Ef vel er að staðið, geta leikskólar pannig verið mikilvægur vettvangur fyrir flóttabörn sem stíga par mörg sín fyrstu skref í menntun, oft í framandi umhverfi. Fyrir pessi börn getur flutningur úr leikskóla í grunnskóla einnig verið sérstök áskorun. Jóhanna Einarsdóttir (2007) hefur bent á að pegar börn hefji grunnskólanám að loknum leikskóla fari pau í raun úr einni menningu eða einum heimi yfir í annan og purfi að takast á við ýmsar breytingar. Hún nefnir að rannsóknir í íslenskum leik- og grunnskólum bendi til pess að algengustu aðferðirnar sem notaðar séu til að tengja skólastigin felist í pví að kynna leikskólabörnum grunnskólann með ýmsu móti. Fátítt sé hins vegar að leikskólakennarar veiti upplýsingar um starfshætti leikskólans eða að grunnskólakennarar leiti eftir peirri vitneskju.

Skólar standa frammi fyrir margvíslegum verkefnum og áskorunum í vinnu með flóttabörnum. Block, Cross, Riggs og Gibbs (2014) benda á að með fjölgun flóttafólks og hælisleitenda sé mikilvægi skólaumhverfisins við að styðja aðlögun og pátttöku flóttabarna viðurkennt í auknum mæli. Skólar geti pó verið illa undirbúnir fyrir að bregðast við hinum ýmsu áskorunum sem flóttabörn glíma við. Ein af áskorunum sem flóttabörn standa frammi fyrir er að læra nýtt tungumál um leið og pau takast á við menntakerfi og félagskerfi sem eru peim ókunnug. Auk pess glíma mörg peirra við áfallastreitu vegna erfiðra skilyrða fyrir komu til nýja landsins. Niðurstöður rannsókna um samvinnu mennta- og heilbrigðisstofnana við móttöku flóttabarna (Jones og Rutter, 1998; Richman, 1998; Rousseau, Measham og Nadeau, 2012; Ziaian, de Anstiss, Antoniou, Sawyer og Baghurst, 2012) benda til pess að mörg flóttabörn eigi erfiða reynslu að baki sem haft getur áhrif á menntun peirra og pví sé samvinna stofnana nauðsynleg til að greina vanda og áfallastreitu flóttabarna og veita viðeigandi pjónustu. Rannsóknir (sjá Hughes, 2014) hafa einnig sýnt að sumar flóttafjölskyldur eigi erfitt með að nálgast og sækja sér geðheilbrigðispjónustu vegna peirrar smánar sem getur tengst pví að purfa á henni að halda og skorts á pekkingu um leiðir sem bjóðast. Раð er pví talið mikilvægt að menntastofnanir og heilbrigðisstofnanir prói sameiginlega leiðir til að styðja flóttabörn (Jones og Rutter, 1998).

Richman (1998) hefur athugað reynslu flóttafólks og flóttabarna, svo sem missi sem pau hafa upplifað og breytingar sem pau upplifa t.d. pegar fjölskyldur sundrast. Slíkar breytingar geta haft mikil áhrif á sjálfsmynd barnanna að mati Richman. Hún bendir pó á að erfið reynsla flóttabarna birtist með mismunandi hætti eftir aldri peirra. Hjá ungum börnum geti hún m.a. birst í aðskilnaðarkvíða og árásargirni. Рað purfi bví að gefa peim nægan tíma til að venjast nýjum aðstæðum. Richman leggur áherslu á traust og gott samstarf skóla og fjölskyldna, auk skapandi starfs fyrir börnin sem veiti peim gleði og styðji við félagsfærni peirra og jákvæða sjálfsmynd. Að sögn Richman purfa foreldrar flóttabarna líka að laga sig að nýjum hlutverkum. Margt flóttafólk sé vel menntað, en menntun peirra sé e.t.v. ekki viðurkennd í nýja landinu. Detta skapi vanlíðan hjá mörgu flóttafólki. Konur í hópi flóttafólks hafa hugsanlega misst fyrra hlutverk sitt sem heimavinnandi húsmæður eða sjálfstæðar útivinnandi konur, sumar eru jafnvel óvanar pví að fara einar út eða vera meðal ókunnugra. Margar konur og einnig mæður ungra barna upplifa pví einangrun í nýja landinu.

Nýlegar rannsóknir með flóttafólki á Íslandi varpa ljósi á hvað má bæta í móttöku og meðferð flóttabarna og fjölskyldna peirra. Markmið eigindlegrar rannsóknar Elsu Hrundar Jensdóttur (2016) með íslensku og sænsku heilbrigðisstarfsfólki var að greina pætti sem bæta mætti í móttöku og meðferð flóttabarna og fjölskyldna peirra á Íslandi og í Svípjóð. Niðurstöður rannsóknarinnar benda til pess að flóttafjölskyldur standi frammi fyrir ýmsum áskorunum, m.a. tengdum tungumálum og aðlögun að nýju landi par sem gildi eru ólík peirra eigin. Foreldrarnir vilja skapa börnum sínum öruggt umhverfi og ný tækifæri sem bjóðast í nýja landinu. Enn fremur benda niðurstöður rannsóknarinnar til pess að verkferlum í heilbrigðiskerfinu sé ábótavant og vanpekking á málefnum flóttafólks og annarra innflytjendahópa í heilbrigðiskerfinu sé töluverð. Dregnar eru pær ályktanir að endurmeta og endurskipuleggja purfi heilbrigðiskerfi Íslands og 
Svípjóðar hvað varðar pjónustu við flóttafólk. Einnig purfi að bæta aðgengi að fræðsluefni og upplýsingum á tungumálum innflytjenda og efla fræðslu til heilbrigðisstarfsfólks með pað fyrir augum að auka menningarnæmi í heilbrigðiskerfinu. Í nýlegri skýrslu Alpjóðamálastofnunar Háskóla Íslands (2017) um greiningu á pjónustu flóttafólks á Íslandi var bent á mikilvægi samstarfs stofnana sem koma að pjónustu við flóttafólk. Par er einnig bent á að efla purfi kennslu i íslensku og huga að aðstæðum ungs fólks.

Rannsóknir á Íslandi sem tengjast menntun flóttabarna benda m.a. til pess að börnunum finnist skólastarf á Íslandi ólíkt pví sem pau áttu að venjast í heimalandinu, pau telji íslenska tungumálið mikilvægt til að geta átt samskipti, en sum eigi jafnframt 1 erfiðleikum með að tengjast íslenskum jafnöldrum sínum. Í niðurstöðum rannsóknar Guðbjargar Ottósdóttur og Helenu N. Wolimbwa (2011) um viðhorf og reynslu flóttabarna á Íslandi kemur m.a. fram að pau telja færni í tungumálinu, svo og viðhorf jafnaldra og samfélagsins í heild skipta mestu máli í aðlögun að íslensku samfélagi. Pau nefna einnig að pó að peim líði vel á Íslandi pá sjái pau ekki fyrir sér að vilja búa hér í framtíðinni. Dau telja námið erfitt en peim gengur pó almennt vel og líður vel.

Fyrstu niðurstöður rannsóknar höfundar og samstarfsfólks (Hanna Ragnarsdóttir og Susan Rafik Hama, 2018a; 2018b) um reynslu flóttabarna, foreldra peirra, kennara og skólastjóra af leik- og grunnskólastarfi og frístundastarfi benda til pess að pó að flestum börnum gangi vel í náminu og pau taki virkan pátt í skólastarfinu, séu undantekningar á pví. Foreldrarnir hafi sumir áhyggjur af pví að börnin læri ekki nóg og eldri börnin standi frammi fyrir ýmsum áskorunum, bæði námslega og félagslega. Sum barnanna og foreldranna glíma við ólæsi og sum barnanna hafa misst nokkur ár úr skóla. Áfallastreita hjá börnunum hefur einnig komið fram. Sum eldri börnin hafa vanist óvinsamlegu umhverfi og eiga erfitt með að skilja og meðtaka væntumpykju annarra barna. Pá gera ólík menning, hefðir og trúarbrögð bæði börnum og foreldrum erfitt fyrir.

Í meistaraverkefni Silju Guðbjargar Hafliðadóttur (2018) beindi hún athygli að sjónarhorni leikskólastarfsfólks sem hefur tekið á móti börnum kvótaflóttafólks og börnum fólks sem sótt hefur um alpjóðlega vernd á Íslandi. Niðurstöður rannsóknarinnar benda til pess að ákveðnar aðferðir og verkfæri reynist vel í samskiptum við börnin, svo sem sjónrænt skipulag og að setja orð á athafnir. Auk pess reynist notkun túlka og vefsíðunnar translate.google.com vel í samskiptum við foreldra peirra. Einnig kemur fram að pörf er á aukinni fræðslu frá öðrum stofnunum og frekara samstarfi par á milli til að styðja betur við kennara.

Prátt fyrir að niðurstöður ýmissa rannsókna hafi bent til pess að margt megi betur fara í skólastarfi með flóttabörnum, hafa fyrri rannsóknir einnig leitt í ljós að skólar í ýmsum löndum hafa próað skólastarf og námsrými fyrir fjölbreytta nemendahópa, par á međal flóttabörn, par sem peim hefur gengið vel námslega og félagslega (sjá Hanna Ragnarsdóttir og Clea Schmidt, 2014; Hanna Ragnarsdóttir, 2016). Í pessum skólum er áhersla lögð á félagslegt réttlæti og jöfnuð, m.a. með fjölbreyttum kennsluháttum, markvissri vinnu með tungumál barnanna og menningu ásamt öflugu samstarfi við foreldra. Keddie (2012), sem kannaði hvernig brugðist er við flóttabörnum í skólum í Ástralíu, telur á sama hátt lykilatriði í skólastarfi fyrir velgengni peirra vera að skapa peim umhverfi án aðgreiningar par sem menning peirra og sjálfsmynd er viðurkennd.

\section{Aðferð og framkvæmd rannsóknar}

Í greininni er fjallað um niðurstöður rannsóknarinnar er snúa að reynslu starfsfólks leikskóla af móttöku og starfi með flóttabörnum úr hópnum og foreldrum peirra fyrsta árið. Eigindlegum aðferðum var beitt í rannsókninni. Eigindlegar aðferðir eru bæði lýsandi og túlkandi og bjóða upp á sveigjanleika í rannsóknarsniði og framsetningu. Pær henta pví vel pegar skoða á félagsleg tengsl (Flick, 2006). Gagnrýnið eigindlegt rannsóknarsjónarhorn var valið par sem pað felur í sér nálgun gagnrýninnar uppeldisfræði sem er umbótamiðuð og valdeflandi (Denzin, Lincoln og Smith, 2008). 
Gagna var aflað með hálfstöðluðum viðtölum við leikskólastjóra, deildarstjóra og annað starfsfólk alls sex leikskóla í premur sveitarfélögum sem tóku á móti kvótaflóttafólki árið 2016. Alls hófu sjö flóttabörn skólagöngu í leikskólunum árið 2016 og voru pá á aldrinum eins árs til fimm ára. Í hálfstöðluðum viðtölum er stuðst við fyrirfram mótaðan viðtalsramma, án pess pó að flæði viðtalsins verði heft með spurningum (Kvale, 1996). Gögnum var safnað í sex viðtölum á tímabilinu frá apríl til júní 2017. Haft var samband við skólaskrifstofur og fengin leyfi til að gera rannsókn í leikskólunum. Síðan var haft samband við leikskólastjórana, peir beðnir um að taka pátt og jafnframt benda á starfsfólk í leikskólunum sem gæti miðlað reynslu sinni af vinnu með flóttabörnunum. Viðtöl voru tekin við alls tólf starfsmenn leikskóla, par af fimm leikskólastjóra, fjóra deildarstjóra og prjá aðra starfsmenn og tóku tveir starfsmenn pátt í hverju viðtali. Viðtölin tóku 60-90 mínútur hvert, fóru öll fram í leikskólunum og voru á íslensku. Viðtölin voru tekin upp og afrituð orðrétt síðar.

Leikskólarnir eru að mörgu leyti ólíkir. Stærð peirra er mismunandi, svo og aldur peirra, stefna og starfshættir. Hlutfall barna af erlendum uppruna er mishátt í leikskólunum sex, en allir hafa peir einhverja reynslu af starfi með fjölbreyttum barnahópum hvað varðar menningu, tungumál og trúarbrögð pó að sú reynsla sé mislöng og viðamikil.

Demagreining (Braun og Clarke, 2013) var notuð til að greina gögnin. Dau voru greind með opinni kóðun og dregin voru fram sameiginleg pemu, síðan var farið yfir pemun til að finna lykilbemu (Flick, 2006). Helstu pemu sem fjallað er um í pessari grein eru niðurstaða pessa greiningarferlis.

Siðareglum um menntarannsóknir hefur verið fylgt í rannsókn peirri sem hér er fjallað um (Kvale, 2007; Sigurður Kristinsson, 2013). Rannsóknin var skráð hjá Persónuvernd. Pátttakendur í rannsókninni voru upplýstir um tilgang hennar, framkvæmd og að nafnleynd peirra yrði tryggð í rannsókninni. Rannsakendur gættu fyllsta trúnaðar við skóla og pátttakendur með pví að upplýsingar væru aldrei rekjanlegar (Flick, 2006). Samkvæmt lögum um persónuvernd og meðferð persónuupplýsinga, 31 gr. nr. 77/2000, pá var pessi rannsókn tilkynningarskyld. Persónuvernd var tilkynnt um framkvæmd rannsóknarinnar áđur en hún hófst, nánar tiltekið 31. ágúst 2016. Jafnframt fylgdu rannsakendur Vísindasiðareglum Háskóla Íslands (2014).

\section{Niðurstöður}

Niðurstöður rannsóknarinnar byggja á viðtölum við leikskólastjóra, deildarstjóra og annað starfsfólk í leikskólunum sex. Meginpemu sem fram komu við greiningu gagna voru: Undirbúningur fyrir komu flóttabarnanna; móttaka barnanna og fyrsta árið; starfshattir; máltaka og málörvun; flutningur í grunnskóla; samstarf foreldra og leikskóla; og menning og trúarbrögd.

\section{Undirbúningur fyrir komu flóttabarnanna}

Móttökuteymi sem samanstóðu af sérfræðingum og verkefnastjórum skipulögðu undirbúning fyrir komu flóttabarnanna og fjölskyldna peirra í sveitarfélögunum premur. Fjölskyldurnar sóttu undirbúningsnámskeið um íslensku og íslenskt samfélag í nokkrar vikur eftir komuna til sveitarfélaganna. Auk pess fékk hver fjölskylda prjár til fimm stuðningsfjölskyldur fyrsta árið, sem aðstoðuðu við daglegt líf, íslenskunám og veittu fjölskyldunum almennan stuðning eftir pörfum.

Enginn leikskólanna hafði áđur tekið á móti flóttabörnum. Skólaskrifstofurnar í sveitarfélögunum premur héldu fundi og námskeið með starfsfólki skóla, par á meðal leikskólanna til að undirbúa komu barnanna par sem m.a. var fjallað um áfallastreitu og reynslu flóttabarna með almennum hætti. Að kennslu á námskeiðunum komu m.a. verkefnastjórar frá Rauða krossinum í málefnum flóttafólks og sálfræðingar. Einnig fjallaði starfsfólk annarra sveitarfélaga um reynslu sína af móttöku flóttafólks. Almennt var starfsfólk leikskólanna ánægt með undirbúninginn. 
Ýmsar leiðir voru notaðaríleikskólunum til að undirbúa börn og foreldra fyrir komu flóttabarnanna og að sögn pátttakenda tóku börnin vel á móti peim. Dæmi voru um að foreldrum hefði verið sendur tölvupóstur par sem kynnt var að leikskólinn væri að taka á móti flóttafjölskyldu. Í viðtölum kom fram að spurningar hefðu vaknað hjá börnunum sem fyrir voru um hvers vegna barn borðaði ekki kjöt. Pátttakendur nefndu að börnin bæru virðingu fyrir pví sem ólíkt væri hjá flóttabörnunum og að pað hefði almennt gengið vel að taka á móti peim. Hvað foreldrana varðar nefndi einn leikskólastjóri að pað hefði verið „feimni til að byrja með í fataklefanum“ en hins vegar hefði alltaf verið „einhver sem talar við pau og pau eiga alveg vini í foreldrahópnum.“ Pannig taldi leikskólastjórinn að almennt hefði verið jákvæðni hjá foreldrum í leikskólanum gagnvart flóttafólkinu.

Dátttakendur lýstu pví hve mikilvægur stuðningur sveitarfélagsins og stuðningsfjölskyldnanna hefði verið, bæði fyrir leikskólana og fjölskyldurnar. Einnig kom fram að í minnsta sveitarfélaginu hefði ríkt almenn jákvæðni gagnvart komu flóttafólksins, sem kannski tengdist smæð staðarins. Einn leikskólastjóri sagði um petta:

... pað var líka bara mjög mikil jákvæðni áđur en pau komu ... pú veist fólk var að gefa hlutina sína til pess að safna í íbúðina fyrir pau og eitthvað svona, pað var ótrúlega mikið af hlutum sem komu, pað var ekki notaður helmingurinn af pví ... petta var vel kynnt hjá bænum ... og vel farið af stað ... bæjarbúar vissu almennt af pessu, tilfinningin fyrir komu fólks var mjög jákvæð.

Dátttakendur nefndu að pað hlyti að vera afar mikilvægt fyrir flóttafólkið að undirbúningur væri svo góður. Að sama skapi veitti pað starfsfólki leikskólanna öryggi hversu vel var haldið utan um undirbúning fyrir komu flóttafólksins og móttöku pess. Einn starfsmaður leikskóla sagði:

... ég held líka að pessi móttaka á peim og pað var búið pegar pau koma, pá voru pau búin að fá húsnæði, pað er tilbúið, pað er einhver sem heldur vel ... stuðningsfjölskyldurnar eru á svæðinu, pað er bara búið að taka stóran hluta af áhyggjunum af peim ... hérna eru bara allir aðilar að vinna ... pað er ... búið að fá tannlækni og heimilislækni og pú veist, liggur við, vinnu og búið að redda öllum skólamálum og íbúð og ... petta er náttúrulega alveg frábært hvernig var staðið að pessu hérna.

Starfsmaður í sama leikskóla bætti við um stuðninginn við foreldrana:

Pannig að maður svona vissi að pau voru í góđum höndum, maður ... sá að pau voru að sleppa einhvern veginn, axlirnar voru komnar niður sko ... pannig að maður fann að pau voru svona að verða öruggari og koma í raun og veru óvenju örugg inn í leikskólann ... kom okkur á óvart sko ... og pað var mjög jákvætt að sjá hvað pau voru tilbúin að aðlagast, hvað pau vildu kynnast skólanum og svona reyna að setja sig inn í hvað var verið að gera.

Einn leikskólastjóri nefndi að búið væri að undirbúa flóttafólkið mjög vel áđur en börnin byrjuðu í skólunum, mun betur en annað fólk sem flytti til landsins:

... pað er mikið búið að vinna með pessa foreldra ... á undan skólagöngunni í rauninni ... pau eru búin að fá miklu ítarlegri kynningu á öllu íslenska kerfinu heldur en fólk sem bara flytur hingað einn daginn og birtist inni á gólfi hjá okkur.

Samskipti leikskólanna við fulltrúa sveitarfélaganna eftir undirbúningsnámskeiðin voru pó mismikil. Á sama hátt voru samskipti leikskólanna við stuðningsfjölskyldurnar mismunandi og í sumum tilvikum engin. Sumir pátttakenda töldu að eftirfylgni og pjónusta frá sveitarfélaginu hefði átt að vera meiri eftir fyrsta árið, en pá var verkefninu um móttöku og stuðning við flóttafólkið lokið af hálfu sveitarfélaganna. Einn leikskólastjóri sagði um petta: „Verkefninu er tæknilega séð lokið ... nú bara björgum við okkur með túlk og pau eru bara almennir borgarar.“ 


\section{Móttaka barnanna og fyrsta árið}

Börnin komu úr mismunandi aðstæðum, sum höfðu upplifað átök en önnur ekki. Dað kom starfsfólki stundum á óvart hversu góðu jafnvægi börnin voru í par sem starfsfólkið hafði verið búið undir annað. Einn leikskólastjóri sagði:

... miðað við pað sem við héldum fyrst miðað við hvernig var talað við okkur ... pá héldum við að við værum að fá bara barn ... beint úr einhverjum hræðilegum tjaldbúðum og bara ... eitthvað en pað var alls ekki pannig.

Sumir foreldrar í hópi flóttafólks höfðu verið í góðri stöðu í Sýrlandi og voru vel menntaðir. Баð kom starfsfólki leikskóla stundum á óvart að fjölskyldurnar voru betur staddar en pað hafði átt von á. Einn leikskólastjóri sagði um petta:

... pau voru með iPada og pau voru með síma og pau voru með eitthvað sem peim hafði áskotnast í Líbanon ... pannig að maður er svona aðeins áttavillt á stöðunni peirra ... einhvern veginn hélt maður að pau væru sko, hefði maður haldið að pau væru beygðari.

Drátt fyrir að fjölskyldurnar væru vel tækjum búnar og virtust vera í góðu jafnvægi í upphafi purfti að styðja við pær með ýmsum hætti og m.a. útvega kulda- og regnföt fyrir börnin. Dá kom einnig í ljós pegar leið á fyrsta árið að líðan foreldra og barna var sveiflukennd. Starfsfólk leikskóla sýndi pessu mikinn skilning, svo og pví hve erfitt pað hlyti að vera fyrir fjölskyldurnar að koma inn í svo gjörólíkt samfélag og aðstæður. Einn leikskólastjóri sagði um unga móður í hópnum:

... petta hlýtur að vera rosalega skrýtið líf og auðvitað ... íslenskir foreldrar orðnir alveg hundleiðir að hanga einir heima með ómálga barn, eins og við erum að byggja upp samfélagið okkar pá nennum við pví ekkert ... og hvernig er pessi kona, ein 1 ókunnugu landi par sem er myrkur næstum pví allan sólarhringinn og núna er bjart allan sólarhringinn ...

Móttaka flóttabarnanna í leikskólunum var skipulögð með svipuðum hætti og móttaka annarra barna af erlendum uppruna í leikskólunum og voru m.a. notaðir túlkar til að eiga samskipti við foreldrana.

Eins og áđur segir voru börnin á aldrinum eins til fimm ára pegar pau hófu leikskólagöngu sína og pví á mismunandi proska- og máltökuskeiði. Almennt gekk aðlögun barnanna vel, svo og samskipti peirra við önnur börn og pátttaka í leikskólastarfinu. Ekki bar á afleiðingum áfalla hjá börnunum, nema hjá einu barni sem sótti í stríðsleiki og átök, en starfsfólkið lagði sig fram um að beina leik barnsins inn á aðrar brautir. Börnin höfðu verið undirbúin sérstaklega fyrir komu flóttabarnsins í sumum leikskólanna og pað gafst vel. Leikskólastjóri og starfsmaður í einum leikskólanum sögðu í pessu samhengi:

... pað var eiginlega bara strax, og hann er mjög vinsæll í hópnum ... pær voru rosalega flottar í að taka á móti honum. Pað var fagstjórinn í tónlist, hún hafði pýtt arabískt lag yfir á íslensku og kenndi börnunum pað á arabísku ... pannig pau sungu pað fyrir hann pegar hann kom ... á arabísku og svo á íslensku líka pannig barnahópurinn ... var undirbúinn ... að taka á móti drengnum ... pau vissu að hann var að koma frá Sýrlandi ... pau voru spennt að fá hann ... og pau voru ofboðslega umhyggjusöm ... og ... umburðarlynd gagnvart honum ... og voru spennt að fá hann inn í leikinn pannig að honum var vel tekið og ég held að pað hafi skilað pví að hann sýnir áhugann á íslenskunni og greinilegt að pau eru metnaðarfull fyrir námi og öðru ... pannig að pað hjálpaðist allt að, pannig hann var nánast orðinn talandi eftir prjá, fjóra mánuði ... við líka vorum með leikhópa, pað voru markvissir leikhópar par sem hann var, við segjum náttúrulega engum „leiktu við hann" en sú stund er bara sköpuð. 


\section{Starfshættir}

Leikskólarnir í rannsókninni eru ólíkir eins og áđur hefur komið fram og par er mismikil reynsla af starfi með börnum af erlendum uppruna. Börnin í leikskólunum hafa tekið virkan pátt í leikskólastarfinu með öđrum börnum en eldri börnin fá sum stuðning við íslenskuna í minni hópum. Sums staðar hefur stuðningur verið veittur við móðurmál barnanna utan skólans.

Starfsfólk leikskólanna nefndi sumt muninn á pví að taka á móti flóttabarni annars vegar og barni af erlendum uppruna hins vegar. Einn leikskólakennari sagði í pessu samhengi að börnin fengju jafnmikinn tíma og önnur börn, en við bættist erfið reynsla foreldra og barna og pví pyrfti að leggja sérstaka áherslu á að skapa traust:

Dannig að parna bætist í rauninni bara áfallið við sem flóttafólk ... og líka foreldrarnir, af pví pau áttu mjög erfitt með að treysta ... og alveg bara, er ekki örugglega hliðið læst af pví hann fer bara heim og alls konar svona líka sem við purfum að sannfæra pau, að hann sé öruggur hér.

एó að börnin tækju pátt í almennu starfi leikskólanna voru farnar ýmsar leiðir í leikskólunum til að stuðla enn frekar að pátttöku barnanna. Dæmi voru um að börnin hefðu sérstakan stuðningsaðila sem fylgdi peim í starfinu. Í einum leikskóla var slíkur stuðningur skipulagður til að auðvelda aðlögun barnsins í upphafi og svo var smám saman dregið úr honum. Stuðningsaðilinn tengdist fjölskyldunni og skapaði traust milli foreldra og leikskóla.

Ýmsar leiðir voru farnar til að skapa traust og öryggi fyrir barnið og til að styrkja tengslin milli leikskóla og foreldra. Samskiptabækur voru notaðar með myndum af foreldrum og systkinum barnsins og starfsfólkinu í leikskólanum og nöfnum peirra. Smám saman var bætt við myndum og hugtökum til að styðja við íslenskuna. Einn leikskólastjóri lýsti pví hvernig samskiptabók hafði nýst foreldrunum jafnt sem börnunum:

Dau voru mjög svona tilbúin að vera með pessa bók alltaf á milli ... pannig að pau voru mjög samviskusöm að koma alltaf með hana á hverjum morgni inn ... sögðust nota hana líka til að læra íslensku.

Leikræn tjáning var einnig notuð til að auðvelda máltöku íslensku. Sýnileiki tungumála allra barna í leikskólanum var einnig notaður til að skapa peim traust og öryggi og efla pau. Dannig var t.d. sungið og talið á arabísku.

\section{Máltaka og málörvun}

Máltaka yngri barnanna í íslensku gekk almennt vel fyrsta árið að sögn starfsfólks leikskólanna sem taldi börnin vera á sama stað og önnur tvítyngd börn. Yngri börn fylgdu öðrum börnum í öllu starfi, en pau eldri fengu sérstakan stuðning í íslensku í leikskólunum eftir pví sem starfsfólkið taldi purfa. Starfsfólk nefndi sérstaklega að pó að börnin væru fljót að ná leikmálinu, vantaði stundum upp á orðaforða hjá eldri börnunum og pá væri reynt að bregðast sérstaklega við pví. Einn leikskólastjóri sagði:

... pau eru alveg í félagslegum samskiptum við börnin hérna, fram að sex ára aldri eru pau alveg að plumma sig en sko fjölbreytnin í orðavali af pví íslenskan er svo auðug og pegar fer að koma pyngra orðalag í bóklestri og petta og ýmsir hlutir sem að kannski við erum ekki að vinna með inn í leikskóla sem ... er bara unnið með heima eins og bara eldhúsáhöld - hvað heitir ausa hvað heitir hitt og petta alls konar ... orðaforði sem bara vantar upp á og við erum sem sagt með átak svolítið í gangi með petta og par með eru pau ... með í pví sko. 
Framfarir barnanna í íslensku fyrsta árið héldust gjarnan í hendur við framfarir foreldranna að sögn starfsfólks leikskólanna. Einn starfsmaður nefndi að barnið hefði pannig verið mjög ánægt pegar móðirin var farin að tjá sig á íslensku:

... pannig að fyrstu kynnin voru bara flott sko og ... pannig ... já pað svona veitti örugglega ákveðið öryggi og maður sá pað líka á honum pegar hún gat notað nokkur orð ... hann svona, honum fannst pað, hann ljómaði svona pínu sko ... en petta er reyndar algert undrabarn og snillingur pessi drengur vegna pess að máltakan hjá honum hefur verið sko mjög góð ... hann er orðinn fullfær á íslenskuna ... tók langan tíma að ná góðri færni og hann er bara jafnfæetis sumum íslenskum jafnöldrum sínum á mörgum sviðum ... pannig að hann kemur vel út í Hljóm-2 og öllu pessu ... samskiptum og hljóðkerfisvitund ... pannig að hann er einstakur og hann náttúrulega, mamman farin að tala talsvert góða íslensku núna.

Фó að framfarir hafi almennt verið góðar hjá börnunum fyrsta árið höfðu leikskólastjórar talsverðar áhyggjur af pví að sum elstu börnin væru ekki tilbúin fyrir grunnskólann að pví loknu. Einn leikskólastjóri nefndi að prátt fyrir góðan stuðning við íslensku og undirbúning fyrir grunnskóla væru ekki öll börn tilbúin fyrir grunnskólann og nefndi dæmi um einn dreng í pessu samhengi, sem leikskólastjóri taldi að hefði e.t.v. heldur ekki verið tilbúinn fyrir grunnskólann í upprunalandinu:

... pannig að varðandi svona undirbúninginn veit ég ekki alveg hvað hann er kominn langt ... pað eru svona líka ákveðnar vísbendingar um að hann sé svolítið ör ... pó að hann væri bara í arabísku samfélagi, hann er svona einbeitingar ... svona ... pað er ómögulegt að vita hvað er hvað ... ég held að pað sé algerlega borin von um að hann sé bara 100\% tilbúinn í grunnskóla varðandi íslenskuna, pað parf einhvern veginn ... аð fylgja pví eftir.

Í sumum leikskólanna var sérstök áhersla lögð á sjónrænt skipulag til að hjálpa börnunum að lesa í umhverfi sitt og að sögn starfsfólksins var pað gagnlegt bæði fyrir börn og foreldra.

Starfsfólk sumra leikskólanna nefndi að börnin virtust fá góðan stuðning við arabískuna heima, en átti erfitt með að meta stöðu peirra í arabísku. Starfsfólk eins leikskóla talaði um að jákvæðni og stuðningur heima fyrir væri greinilega að veita barninu góðan stuðning:

... pannig að hann í raun og veru með sinni jákvæðni og bara ... við sjáum líka eins og með hann að ... pað er greinilega vel haldið utan um hann heima ... hann er með gott ... bakland, talar arabískuna náttúrulega vel og með góðan grunn í móðurmálinu ... fyrir vikið gengur honum vel ... máltakan á íslensku gengur pá vel ... af pví hann hefur ... og pað er verið að bæta á orðaforðann hans á arabísku, pau eru greinilega að syngja og lesa pú veist ... pað er verið að vinna, sem skiptir rosalega miklu.

Einnig nefndi starfsfólkið að góður grunnur í móðurmálinu veitti börnunum forskot. Einn leikskólakennari sagði um petta:

рað sem við höfum svona verið að velta fyrir okkur hvort að sé, er hann svona góður af pví hann var búinn að ná svona góđri færni á sínu máli - af pví mér finnst pad alltaf koma svona meira og meira inn að krakkar sem eru með góðan grunn og vel fær í sínu tungumáli, pau eiga auðveldara með að tileinka sér næsta tungumál.

Hjá yngri börnunum var lögð áhersla á sambærilegar kröfur til peirra og annarra barna par sem pau væru á máltökuskeiði og mætti ekki gera of miklar kröfur til peirra.

\section{Flutningur í grunnskóla}


Prjú af börnunum voru að ljúka leikskólagöngu pegar viðtölin voru tekin og undirbúningur fyrir grunnskólagöngu peirra hafinn með markvissu samstarfi við grunnskólana. Starfffólk leikskóla nefndi sumt að foreldrar ættu erfitt með að átta sig á að leikskólinn lokaði um sumarið eða að börnin færu í sumarfrí áður en grunnskólinn hæfist. Einnig ættu peir erfitt með að skilja að peir pyrftu að borga fyrir heilsdagsvistun barnanna í grunnskólanum.

Starfsfólk leikskólanna taldi víst að börnin færu í almennan fyrsta bekk með öðrum börnum, enda stæðu pau jafnfæetis jafnöldrum sínum. Leikskólastjórar töldu pó sumir að líklegt væri að börnin pyrftu að fá sérstakan stuðning við íslenskuna a.m.k. fyrst um sinn. Einn leikskólastjóri sagði:

... að sjálfsögðu er stafrófið, petta er allt tvöfalt fyrir hann ... af pví hann er að læra arabísku heima líka ... en hann bara stendur sig mjög vel ... í rauninni ... í málinu og ... já kannski aðeins slakari eins og að ríma og pað er svona ... hann verður örugglega seinni til að lesa ... en pað er allt eitthvað sem er hægt að halda utan um ... og pað væri náttúrulega ekkert verra ef hann fengi einhverja sérkennslu til pess að hvetja hann áfram.

Degar spurt var um móðurmálskennslu barnanna kom fram í viðtölunum að í sumum tilvikum hefði verið rætt að grunnskólinn sæi um að útvega arabíska móðurmálskennslu.

Í viðtölunum var rætt um matstæki og hvort sérstök tæki væru notuð til að meta kunnáttu barnanna og annarra tvítyngdra barna. Starfsfólkið nefndi að um sama mat væri að ræða og hjá öđrum börnum, p.e. málproskamat í kringum priggja ára aldurinn sem tæki á skilningi, framburði og tjáningu og svo Hljóm-2 próf í kringum fimm ára aldurinn. Einn leikskólastjóri nefndi að barnið hefði ekki komið vel út í Hljóm-2 prófinu, enda væri ekki hægt að ætlast til pess eftir eitt ár í leikskólanum. Grunnskólinn myndi hugsanlega skipuleggja eitthvað í framhaldi af skilafundum milli leikskólans og grunnskólans. Starfsfólk nefndi að foreldrarnir væru hvattir til að nýta sér námskeið sem grunnskólinn byði áður en hann hæfist um haustið.

\section{Samstarf foreldra og leikskóla}

Starfsfólk leikskólanna var ánægt með samstarfið við foreldrana og pakkaði pað bæði góðum undirbúningi af hálfu sveitarfélagsins og vilja fjölskyldnanna til samstarfs. Pó að fjölskyldurnar séu ólíkar að mörgu leyti, t.d. hvað varðar fjölda barna, aldur foreldra, menntun, stöðu í upprunalandinu og reynslu af átökum gekk foreldrasamstarfið almennt vel að sögn starfsfólks leikskólanna. Undirbúningurinn skilaði sér að mati starfsfólksins í pví að samskiptin gengu vel frá upphafi. Auk pess var starfsfólk sumra leikskólanna búið að undirbúa sig aukalega fyrir komu flóttafólksins með ýmsum hætti. Að sögn starfsmanns eins leikskóla voru foreldrarnir mun öruggari en hann bjóst við:

Óvenju örugg ... og við náttúrulega vorum aðeins svona búin að kynna okkur ... peirra menningu, við svona bara sáum um pað svolítið sjálfar ... bara svona ... af pví að margt í menningunni peirra, eins og í trúnni og pannig, með matarmenninguna og allt svoleiðis pannig við vorum búin að pú veist undirbúa eldhúsið og allt petta ... pví pað er náttúrulega, hann borðar ekki kjöt sem er venjulega slátrað eins og við og pannig skilurðu ... pannig petta svona, við vorum búin að undirbúa okkur vel með pað ... svo var pað líka pannig að pað var fyrir tilviljun var einn kennari í húsinu ... hafði örlítinn grunn í arabísku.

Tungumálakunnátta foreldranna var mjög mismunandi, sumir höfðu góða enskukunnáttu, en aðrir voru ólæsir á móðurmál sitt og önnur tungumál. Mismunandi tungumálakunnátta hafði áhrif á samskiptin, en prátt fyrir pað voru foreldrarnir að sögn starfsfólksins yfirleitt mjög jákvæðir gagnvart leikskólunum. 
Starfsfólk leikskólanna nefndi sumt að prátt fyrir að pakklæti og eftirvænting hefði verið mikil hjá foreldrunum fyrst um sinn, hefði jafnframt borið á óöryggi peirra svo að töluverður tími fór í að skapa traust. Einnig upplifði sumt starfsfólk að foreldrum liði ekki vel í fjölmenni pegar viðburðir voru í leikskólanum svo sem útskrift elstu barnanna og velti fyrir sér ástæðum pess. Einn leikskólastjóri sagði um petta:

Dau eru svona pínu flóttaleg. Deim líður ekkert rosalega vel í pessum aðstæðum ... pau koma svolítið seint alltaf eða eru einhvern veginn að lauma sér inn, greyin pannig ég veit ekki hvernig peirra líðan er gagnvart pessu ... en pau eru svona, eru að uppfylla pessar væntingar sem fólk er að gera til peirra með pátttöku.

Leikskólastjórinn bætti við:

... svo vorum við að reyna, af pví ég var að reyna að útskýra hvernig væru hefðirnar hérna með útskriftina, börnin væru fín og bara láta pau vita svo að peirra barn væri náttúrulega ekki bara, ekki bara í venjulegum fötum, hin flest öll fín pannig að, en pá kom öll fjölskyldan bara mjög fin sko, bara alveg í sínu ábyggilega finasta pússi.

Upplýsingum til foreldra var komið til skila með túlkum á öllum foreldrafundum og samskiptum, en pegar leið á árið dró úr túlkun í almennum samskiptum eftir pví sem foreldrarnir lærðu íslenskuna betur. Dó nýtti starfsfólk leikskólanna túlk pegar rætt var við foreldra um matstæki og aðra flóknari hluti tengda leikskólastarfinu. Degar á leið voru upplýsingar sendar til foreldra með tölvupósti eða SMS. Í sumum leikskólanna var skólanámskráin, bæklingar um leikskólastarfið og dagskipulag pýtt á móðurmál foreldra. Starfsfólkið nefndi líka að pað notaðist við ýmislegt til að eiga dagleg samskipti, svo sem google translate, táknmál og bendingar.

Degar leið á fyrsta árið fóru pó áhyggjur og vonbrigði sumra foreldra að aukast. Starfsfólk leikskóla talaði um hæðir og lægðir í líðan foreldranna og að pað hefði verið búið undir pað. Einn leikskólastjóri sagði:

Detta með svona hæðir og lægðir var algjörlega eins og Rauði krossinn hafði talað um. Í upphafi að pað er allt spennandi. Pú ert að koma í öryggið og pað er allt nýtt og pú ert að fá svolítið upp í hendurnar og svo ertu svolítið einn og pú parft að finna út úr pessu og pá kemur hérna ... pú veist petta er svona ferðalag.

Annar leikskólastjóri sagði um petta:

Mér finnst áfallið vera að koma núna hjá peim. Fyrst pegar pau komu pá voru pau ofsalega pakklát ... pau voru svona glöð og eftirvæntingarfull og tilbúin að læra og svona. Núna finnst mér pau frekar bitur ... og pau fá ekki jafn mikið og hin fjölskyldan. Dað er minna verið að gera fyrir pau og svona, já, ég upplifi svona depurð og vantraust.

Sumir leikskólanna gripu til sinna ráđa til að styðja við foreldra. Dæmi var um að móður eins barns var boðið starf í leikskólanum ,til að ná henni út“, eins og leikskólastjóri orðaði pað. Að sögn leikskólastjórans hafði hún einangrast svolítið:

Hún kom aldrei í leikskólann. Við erum búin að sjá hana kannski í mesta lagi fjórum sinnum á pessu ári ... hún kemur ekki með barnið, sækir barnið ekki ... er bara heima pannig að við svona ... fannst petta vera svona samfélagslegt verkefni og eiga pínu hlut 1 pessu fólki pannig að aðstoðarskólastjóranum datt petta í hug að prufa petta ... og pað er að gefast ágætlega, hún náttúrulega skilur ekkert ... en hún er að reyna og pað er miklu ... pað eru framfarir sko og petta hefur mjög góð áhrif á drenginn ... maður sér að petta eflir hann, mamma mín er líka að vinna ... pú veist, hann svarar pví, nú er mamma hans komin að vinna ... og hann er að kenna henni íslensku segir hann. 
Starfsfólkið nefndi að sumir foreldranna ættu erfitt vegna aðstæðna fjölskyldu sinnar á átakasvæðum og að hugsanlega truflaði pað aðlögun peirra. Einn leikskólastjóri sagði um móður:

Hún var voða svona, pað sem við vitum er að hún hugsaði mikið heim, hún hugsaði mikið til fjölskyldunnar sinnar úti ... hún var voða upptekin af pví og átti erfitt með að einbeita sér að pví að læra íslensku og að komast inn í samfélagið af pví hún var með hugann par.

Að loknu fyrsta árinu pegar fjárhagsstuðningi við fjölskyldur lauk purftu foreldrar að finna sér vinnu og sumir fengu aðstoð við pað. Starfsfólk leikskólanna nefndi að petta hefði reynst mörgum foreldrum erfitt. Í stærri fjölskyldunum par sem börnin stunduðu nám í mismunandi skólum og jafnvel í ólíkum sveitarfélögum snerist líf foreldranna um að fara með börnin í skólana og sækja pau og peim fannst sumum erfitt að stunda vinnu samhliða pví.

Nokkur dæmi voru um aðstæður par sem pátttakendur töldu að foreldrar hefðu átt erfitt af menningar- og trúarlegum ástæðum. Eitt dæmi var um sumarhátíð sem haldin var í leikskóla. Leikskólastjóri lýsti pví hvernig misskilningur olli pví að boðið var upp á pylsur á tíma föstu hjá foreldrunum og að pað hefði gert peim erfitt fyrir. Hún sagði um petta:

... pað var sumarhátíðin, pá komu pau ... fóru snemma já en pað var líka, pað var einhver misskilningur og hún var akkúrat á peim tíma sem að pau eru í föstu ... við vorum að grilla pulsur og petta var svona kannski eitthvað ópægilegt.

Foreldrarnir voru pó almennt jákvæðir gagnvart siðum og venjum leikskólanna. Einn leikskólastjóri sagði:

... pað má kannski líka bæta pví við að pau hafa verið mjög jákvæð og tekið pátt í íslenskum siðum og venjum ... bara eins og með jólin, við kynntum jólasveinana og hann fékk í skóinn og vissi hvað peir hétu af pví pabbinn fékk bók hjá [starfsmanni] og ... hann vissi af hverju Gáttapefur hét Gáttapefur ... pað var alla leið, og hann fékk að fara með okkur í kirkju ... sem er mjög jákvætt.

prátt fyrir að pað bæri á kvíða og óöryggi hjá sumum foreldrum pegar leið á fyrsta árið var próunin öðruvísi hjá öðrum foreldrum að sögn starfsfólks leikskólanna. Tveir starfsmenn sögðu um fjölskyldu barns:

... svona eftir pví sem að vikur og mánuðirnir liðu pá fór hún svona meira ... eins og mamman og pabbinn að pú veist svona meira að brosa framan í okkur ... maður fann bara að pau urðu alltaf svona öruggari ... mamman náttúrulega bara eins sólargeisli hérna alltaf ... já pau eru bara algerlega frábær ... petta er ótrúlegt fólk sko.

Dessir foreldrar töluðu ekki ensku en voru duglegir að spreyta sig á íslenskunni að sögn starfsfólksins. Starfsfólkið gerði sér pó grein fyrir að pað væri ekki sjálfsagt mál að samstarf við foreldra gengi svo vel sem raun bar vitni:

... petta er svona ótrúlega eitthvað jákvætt fólk sem að bara virkilega vill einhvern veginn nálgast petta nýja líf ... og ... taka pátt í pví sem er verið að gera ... ég held að við höfum verið alveg ótrúlega heppin með ... pessa fjölskyldu ... eins og ég segi ... úr öllu pessu sorglega ferli sko ... pá einhvern veginn varð allt svo jákvæett.

Starfsfólk leikskólanna hafði líka skilning á pví að pað væri ekki ein rétt leið til að eiga góð samskipti við foreldra. Einn leikskólastjóri sagði um petta:

... en pað sem að kannski svo gerist sko, pað er ekki til ein uppskrift ... pá kannski förum við að reka okkur á fyrst eftir að börnin byrja ... við erum ofboðslega heppin samt með fjölskyldur. 
Dátttakendur voru að eigin sögn undirbúnir fyrir að samskipti við foreldra gætu reynt á og orðið erfið og sögðust pví sumir vera pakklátir fyrir að samskiptin gengu vel.

\section{Menning og trúarbrögð}

Ekki höfðu orðið miklir erfiðleikar vegna menningarlegra og trúarlegra pátta að sögn starfsfólks leikskólanna og taldi pað að góður undirbúningur, bæði á námskeiðum á vegum sveitarfélaganna og í leikskólunum hefði komið í veg fyrir slíka erfiðleika. Einn leikskólastjóri nefndi að starfsfólk leikskólans hefði fengið fyrirlestur um fordómaleysi og að vera opinn fyrir ólíkum menningarheimum. Hún benti á að pað sæist á konunum að pær kæmu úr öðrum heimi og að pað eitt gerði fólk kannski forvitið. Pá væru tímasetningar stundum í lausu lofti hjá foreldrunum og pyrfti að gera kröfur um að pau fylgdu dagskrá leikskólastarfsins. Einnig vantaði foreldrana stundum öryggisbúnað fyrir börnin í bílunum, en pau brugðust við pegar peim var bent á að slíkt væri skylda á Íslandi. Í leikskólunum var almennt talað um að menningar- og trúarlegur munur væri ekki hindrun fyrir pátttöku barnanna.

Leikskólastjórarnir töluðu um að pað væri misjafnt eftir fjölskyldum hve mikið pær fylgdu hefðum múslima, en í flestum tilvikum áttu börnin ekki að fá svínakjöt samkvæmt óskum foreldra. Einn leikskólastjóri sagði pó að pað hefði komið starfsfólkinu á óvart hve afslappaðir foreldrar væru varðandi petta:

Við vorum mikið að velta fyrir okkur, við vorum eitthvað að spá í páskana ... já og hann gaf pau skilaboð eins og einhvern veginn pau væru kristin ... pá skildum við ekkert af hverju hún væri með slæðu, en við höfum ekkert farið lengra með pað ... en við vorum svo hissa já, af hverju er petta svona og eitthvað, en kannski virðast pau vera ekkert rosalega stressuð yfir pessu sem fjölskylda að við séum að halda okkur í einhverju, réttum megin með peirra menningu, pau eru svona frekar afslöppuð sko ... við spurðum einmitt meðal annars varðandi fæði, ef óvart myndi gerast að hann fengi svínakjöt ... pá væri pað bara svoleiðis ... en samt erum við ... alltaf að passa.

Hjá börnunum í leikskólunum höfðu ekki komið upp erfiðleikar eða átök sem tengdust menningarmun fyrsta árið. Starfsfólk í leikskólunum nefndi pó að börnin skynjuðu sum sjálf að pau væru á einhvern hátt öđruvísi en hin börnin. Starfsmaður í einum leikskóla nefndi dæmi um barn sem borðaði ekki kjöt í leikskólanum. Degar hann sæi hina krakkana vera að borða kjöt segði hann af og til: „Ég fer að borða kjöt pegar ég er hvítur.“

\section{Umræður og lokaorð}

Hér hefur verið fjallað um helstu niðurstöður viðtala við starfsfólk sex leikskóla um reynslu pess af móttöku og starfi með flóttabörnum og foreldrum peirra fyrsta árið. Fjallað hefur verið um undirbúning á vegum sveitarfélagsins og í leikskólunum fyrir komu barnanna, móttöku peirra, starfshætti í leikskólunum, máltöku og málörvun, flutning í grunnskóla, samstarf við foreldra og menningu og trúarbrögð.

Niðurstöður benda til pess að börnunum vegni vel í leikskólunum, móttaka og samstarf við foreldra hafi almennt gengið vel, ekki síst vegna góðs undirbúnings fyrir komu flóttabarnanna. Баð eru pó ærin verkefni sem leikskólarnir standa frammi fyrir, og snerta m.a. málörvun, flutning í grunnskóla og ólík tungumál og menningu.

Starfshættir leikskólanna eru fjölbreyttir og lögð er áhersla á pátttöku barnanna í leik og starfi. Misjafnt er hvernig unnið er með börnunum í leikskólunum og fer pað eftir áherslum í starfi í hverjum leikskóla. Hvað málörvun flóttabarnanna varðar, fer hún aðallega fram í hópum með öðrum börnum, en eldri börnin fá sérstakan stuðning nokkra tíma á viku. Mjög fáir kennarar 
tala bæði íslensku og arabísku, en stuðningsaðilar og túlkar hafa verið fengnir inn í skólana til að styðja börnin fyrst um sinn. Túlkar hafa pó fyrst og fremst verið nýttir á foreldrafundum.

Í skólunum fer ekki fram markviss kennsla á móðurmáli barnanna, arabísku, en tungumál barnanna í leikskólunum, par með talin arabíska, eru gerð sýnileg með ýmsum hætti og börnin telja og syngja á peim. Slíkar áherslur eru í anda fjöltyngismenntunar til félagslegs réttlætis sem Chumak-Horbatsch (2012), Cummins (2001, 2004) Skutnabb-Kangas o.fl. (2009) og fleiri hafa fjallað um. Đó mætti áhersla á móðurmál vera mun sterkari í leikskólunum, en í viðtölunum kom fram að skilningur væri fyrir hendi hjá starfsfólki um mikilvægi móðurmálsins og að vilji væri til að styrkja móðurmálið í leikskólunum. Leikskólarnir leggja áherslu á að kenna börnunum íslensku og hjá eldri börnunum er sterk áhersla á að undirbúa pau fyrir grunnskólann (Jóhanna Einarsdóttir, 2007), en starfsfólk leikskólanna hefur sumt áhyggjur af pví hvernig börnunum muni vegna í grunnskólunum.

Samstarf við foreldra hefur gengið vel í leikskólunum fyrsta árið. Starfsfólkið sem rætt var við var ánægt með samstarfið og fram kom virðing og umhyggja fyrir foreldrunum og börnunum. Starfsfólkið hafði fengið margvíslega fræðslu, m.a. um ólíka menningu, umburðarlyndi og fordóma og mætti foreldrum með opnum huga. Fræðslan var pó nokkuð ólík bæði eftir sveitarfélögum og leikskólum. Starfsfólkið dáđist margt af pví hve mikið foreldrarnir lögðu á sig í nýju hlutverki og nýjum aðstæðum. Víðsýni og opinn hugur var pannig áberandi hjá starfsfólkinu, og prátt fyrir аð раð hefði ekki fengið markvissa pjálfun í fjölmenningarlegri menntun (Banks, 2013; Nieto, 2010) eða fjöltyngisfræðum (Chumak-Horbatsch, 2012; Cummins, 2001, 2004) var starf pess að mörgu leyti í anda peirra fræða af viðtölunum að dæma.

Dó að starfsfólk leikskólanna hafi verið búið undir áfallastreitu flóttabarnanna og fjölskyldna peirra eins og rannsóknir Richman (1998), Rousseau o.fl. (2012) og Ziaian og félaga (2012) um flóttabörn í skólum hafa leitt í ljós, hefur lítið borið á henni hjá börnunum í leikskólunum að sögn starfsfólksins. Hins vegar nefna sumir pátttakenda að breytingar hafi orðið á líðan sumra foreldra pegar leið á fyrsta árið. Kvíði og efi hafi tekið við af pakklæti og eftirvæntingu hjá sumum foreldranna.

Af helstu niðurstöðum rannsóknarinnar má ráđa að mikilvægt er að styrkja samstarf foreldranna og leikskólanna, og styðja starfsfólk leikskóla enn frekar með aukinni fræðslu og menntun á sviði fjöltyngismenntunar, fjölmenningarlegrar menntunar og kennslu íslensku sem annars máls. Jafnframt mætti fjölga starfsfólki sem talar bæði íslensku og arabísku til að styðja börnin og móðurmál peirra, svo og skapa betri tengsl og traust við fjölskyldurnar í upphafi. Með peim hætti mætti jafnframt stuðla að bættri líðan foreldra pegar líður á fyrsta árið og tímabili eftirvæntingar lýkur.

\section{"There isn't a single recipe" Refugee children's first year in preschools in three municipalities in Iceland}

In 2016, eleven Syrian quota refugee families arrived in Iceland from Lebanon and settled in three municipalities (Stjórnarráð Íslands [Iceland Government Offices], 2019). This longitudinal qualitative interview study aims at understanding the experiences of these adults and their children in their preschool and compulsory school settings and leisure time activities; and to explore the experiences of principals and teachers in their schools and leisure time centres of the children's reception, studies and educational partnerships with their parents. This article presents the findings of interviews with staff in six preschools in the three municipalities concerning the experiences of the reception and the first year of the children's schooling. Altogether seven refugee children from the group, which arrived in 2016, attended these six preschools. They were one to five-years old when they started preschool in 2016. The 
theoretical framework of the study includes critical approaches to education (Banks, 2013; May \& Sleeter, 2010; Nieto, 2010) and multilingual education for social justice (Chumak-Horbatsch, 2012; Cummins, 2004; Skutnabb-Kangas, Phillipson, Mohanty \& Panda, 2009). These approaches provide an important framework for critically addressing educational experiences of children and suggesting improvement. Methods included six semi-structured interviews with principals, heads of divisions and other staff in the children's preschools, altogether twelve individuals. The interviews were conducted in April-June 2017 in the preschools. Two individuals from each preschool participated in each interview. A thematic analytical approach (Braun \& Clarke, 2013) was applied to analyze the data. The main themes derived from the data were: preparation for the arrival of the children; reception of the children and the first year; educational practices; language acquisition; transition to compulsory school; educational partnerships with parents; and culture and religion. The preschools differ in many ways, including size and age, policy and practices. The ratio of children with foreign background in the preschools differs, while all the preschools have some experience of working with culturally and linguistically diverse groups of children. The findings indicate that the children are doing well in the preschools and the educational partnerships with the parents have been largely successful, not least because of thorough preparations before the children's arrival. However, the preschools have many tasks and challenges to address, including for example the children's emergent bilingualism and different cultural heritage. Educational practices in the preschools are inclusive and diverse and active participation of the children is emphasized in free play as well as organized activities. The older children get extra support in Icelandic in small groups with other emergent bilingual children. The schools do not provide mother language support in Arabic; however, their language and other languages are made visible in various ways in the schools and the children sing and count in different languages. Such emphasis is in line with multilingual education for social justice which ChumakHorbatsch (2012), Cummins (2001, 2004), Skutnabb-Kangas et al. (2009) and others have emphasized. The staff show respect and open-mindedness towards the culture and religion of the families and respect their effort of adapting to very different social and cultural conditions in Iceland. The staff are generally not trained in multicultural and multilingual education (Banks, 2013; Chumak-Horbatsch, 2012; Cummins, 2001, 2004; Nieto, 2010), however, the educational practices in the preschool adhere to such emphasis in many ways, according to the findings. Although most of the families are doing well after the first year, the staff note that some of the parents are becoming increasingly worried as time passes and that this could be related to concerns about their children's future. The findings indicate that educational partnerships with parents could be strengthened further in the preschools and that professional development of the staff in multilingual and multicultural education, as well as Icelandic as a second language, could provide a stronger educational and social basis for the refugee children. Hiring Arabic speaking staff for building bridges between preschool and parents and supporting the children would also be beneficial.

Key words: Refugee children, preschools, families, challenges. 


\section{Um höfund}

Hanna Ragnarsdóttir (hannar@hi.is) er prófessor í fjölmenningarfræðum við Menntavísindasvið Háskóla Íslands. Hún lauk M.Sc.-prófi í mannfræði frá London School of Economics and Political Science árið 1986 og Dr.philos-prófi í menntunarfræði frá Háskólanum í Osló árið 2007. Rannsóknir hennar hafa einkum snúist um börn og fullorðna af erlendum uppruna, flóttafólk í íslensku samfélagi og skólum og ýmsa pætti fjölmenningarlegs skólastarfs.

\section{About the author}

Hanna Ragnarsdóttir (hannar@hi.is) is Professor of Multicultural Studies at the School of Education, University of Iceland. She completed an M.Sc. degree in Anthropology from the London School of Economics and Political Science in 1986 and a Dr.philos in Education from the University of Oslo in 2007. Her research has mainly focused on immigrants and refugees (children, adults and families) in Icelandic society and schools, multicultural education and school reform.

\section{Heimildir}

Alpjóðamálastofnun Háskóla Íslands. (2017). Greining á pjónustu við flóttafólk. Skýrsla unnin af Alpjóðamálastofnun Háskóla Íslands fyrir Innanríkisráduneytið og Velferđarráduneytið. Sótt af http://ams.hi.is/wp-content/ uploads/2017/02/Flottamannaskyrsla2017.pdf

Banks, J. A. (2013). Multicultural education: Characteristics and goals. Í J. A. Banks og C. A. M. Banks (ritstjórar), Multicultural education. Issues and perspectives (8. útgáfa, bls. 3-23). New York: John Wiley and Sons.

Block, K., Cross, S., Riggs, E. og Gibbs, L. (2014). Supporting schools to create an inclusive environment for refugee students. International Journal of Inclusive Education, 18(12), 1337-1355. doi:10.1080/136031 16.2014.899636

Braun,V. og Clarke,V. (2013). Successful qualitative research: A practical guide for beginners. London: Sage.

Chumak-Horbatsch, R. (2012). Linguistically appropriate practice: A guide for working with young immigrant children. Toronto: University of Toronto Press.

Cummins, J. (2001). Bilingual children's mother tongue: Why is it important for education? Sprogforum, 19, 15-20.

Cummins, J. (2004). Language, power and pedagogy: Bilingual children in the crossfire (3. útgáfa). Clevedon: Multilingual Matters.

Denzin, N. K., Lincoln, Y. S. og Smith, L.T. (ritstjórar). (2008). Handbook of critical and indigenous methodologies. Thousand Oaks, CA: Sage.

Eisenbruch, M. (1988). The mental health of refugee children and their cultural development. International Migration Review, 22, 282-300. Sótt af https://www.jstor.org/stable/pdf/2546651.pdf?refreqid=excelsior\%3A690e0d9c72aa4209d240207550995e7c

Elsa Hrund Jensdóttir. (2016). Reception of refugee children and their families in healthcare. Healthcare professionals' point of view (óútgefin meistararitgerð). Háskóli Íslands, Reykjavík.

Flick, U. (2006). An introduction to qualitative research (3. útgáfa). London: Sage.

Guðbjörg Ottósdóttir og Helena N. Wolimbwa. (2011). Flóttabörn á Íslandi: Rannsókn á viðhorfum og reynslu flóttabarna. Ritröd um rannsóknarverkefni á sviði félagsrádgjafar, 4. Reykjavík: Rannsóknastofnun í barna- og fjölskylduvernd (RBF) og Félagsráđgjafardeild Háskóla Íslands. 
Hanna Ragnarsdóttir. (2016). Námsrými félagslegs réttlætis og menntunar án aðgreiningar. Niðurstöður norrænnar rannsóknar um velgengni nemenda af erlendum uppruna og skóla á fjórum Norðurlöndum. Sérrit Netlu 2016 - Námsrými félagslegs réttlatis og menntunar án adgreiningar / Learning spaces for inclusion and social justice. Sótt af http://netla.hi.is/serrit/2016/namsrymi_felagslegs_rettlaetis_og_menntunar_an_adgreiningar_learning_spaces_for_inclusion_and_social_justice/001.pdf

Hanna Ragnarsdóttir og Clea Schmidt (ritstjórar). (2014). Learning spaces for social justice: International perspectives on exemplary practices from preschool to secondary school. London: A Trentham Book. IOE Press.

Hanna Ragnarsdóttir og Susan Rafik Hama. (2018a). Flóttabörn í íslenskum skólum: Móttaka, skólastarf og samstarf við fjölskyldur. Glæður. Fagtímarit Félags sérkennara á Íslandi, 28, 57-66.

Hanna Ragnarsdóttir og Susan Rafik Hama. (2018b). Refugee children in Icelandic schools: Experiences of families and schools. Í Hanna Ragnarsdóttir og Samúel Lefever (ritstjórar), Icelandic studies on diversity and social justice in education (bls. 82-104). Newcastle upon Tyne: Cambridge Scholars Publishing.

Hones, D. F. og Cha, C. S. (1999). Educating new Americans: Immigrant lives and learning. Mahwah, NJ: Erlbaum.

Hughes, G. (2014). Finding a voice through 'The tree of life': A strength-based approach to mental health for refugee children and families in schools. Clinical Child Psychology and Psychiatry, 19(1), 139-153. Sótt af http://journals.sagepub.com/doi/abs/10.1177/1359104513476719

Jones, C. og Rutter, J. (ritstjórar). (1998). Refugee education: Mapping the field. Stoke on Trent:Trentham.

Jóhanna Einarsdóttir. (2007). Lítil börn með skólatöskur:Tengsl leikskóla og grunnskóla. Reykjavík: Háskólaútgáfan og Rannsóknastofa í menntunarfræðum ungra barna.

Keddie, A. (2012). Pursuing justice for refugee students: Addressing issues of cultural (mis)recognition. International Journal of Inclusive Education, 16(12), 1295-1310. Sótt af http://www.tandfonline.com/doi/ full/10.1080/13603116.2011.560687?src= recsys

Kvale, S. (1996). InterViews: An introduction to qualitative research interviewing. California: Sage.

Kvale, S. (2007). Doing interviews. London: Sage.

May, S. og Sleeter, C. E. (2010). Introduction. Critical multiculturalism:Theory and praxis. Í S. May og C. E. Sleeter (ritstjórar), Critical multiculturalism: Theory and praxis (bls. 1-16). New York: Routledge.

Nieto, S. (2010). The light in their eyes: Creating multicultural learning communities [10 ára afmælisútgáfa]. New York: Teachers College Press.

Richman, N. (1998). In the midst of the whirlwind: A manual for helping refugee children. Stoke on Trent:Trentham.

Robinson, K. H. og Díaz, C. J. (2006). Diversity and difference in early childhood education: Issues for theory and practice. Maidenhead: Open University Press.

Rousseau, C., Measham, T. og Nadeau, L. (2012). Addressing trauma in collaborative mental health care for refugee children. Clinical Child Psychology and Psychiatry, 18(1), 121-136. Sótt af http://journals.sagepub. com/doi/pdf/10.1177/1359104512444117

Sigurður Kristinsson. (2013). Siðfræði rannsókna og siðanefndir. Í Sigríður Halldórsdóttir (ritstjóri), Handbók i aðferðafraði rannsókna (bls. 71-88). Akureyri: Háskólinn á Akureyri.

Silja Guðbjörg Hafliðadóttir. (2018). Móttaka og kennsla barna flóttafólks í leikskólum á Íslandi: Sjónarhorn deildarstjóra og sérkennara (óútgefin meistararitgerð). Háskóli Íslands, Reykjavík.

Siraj-Blatchford, I. (2006). Diversity, inclusion and learning in the early years. Í G. Pugh og B. Duffy (ritstjórar), Contemporary issues in the early years (4. útgáfa, bls. 107-118). London: Sage.

Skutnabb-Kangas, T., Phillipson, R., Mohanty, A. K. og Panda, M. (ritstjórar). (2009). Social justice through multilingual education. Bristol: Multilingual Matters.

Stjórnarráð Íslands. (2013). Viðmiðunarreglur flóttamannanefndar. Sótt af https://www.stjornarradid.is/verkefni/ utlendingar/flottafolk/adlogun-flottafolks/vidmidunarreglur-flottamannanefndar/

Stjórnarrád Íslands. (2019). Fjöldi flóttamanna. Sótt af https://www.stjornarradid.is/verkefni/utlendingar/ flottafolk/fjoldi-flottamanna/

Velferðarráðuneytið. (2014). Leiðbeinandi reglur fyrir sveitarfélög um móttökupjónustu og aðstoð við félagslega pátttöku flóttafólks. Sótt af https://www.stjornarradid.is/media/velferdarraduneyti-media/media/rit-ogskyrslur-2014/leidb.reglur.LOK.pdf 
Vísindasiðareglur Háskóla Íslands. (2014). Sótt af https://www.hi.is/sites/default/files/atli/pdf/log_og_reglur/ vshi_sidareglur_16_1_2014.pdf

Ziaian, T., de Anstiss, H., Antoniou, G., Sawyer, M. og Baghurst, P. (2012). Depressive symptomatology and service utilisation among refugee children and adolescents living in South Australia. Child and Adolescent Mental Health, 17(3), 146-152. Sótt af http://onlinelibrary.wiley.com/doi/10.1111/j.1475-3588.2011.00620.x/full

Pórdís Dórðardóttir. (2016). Jafnrétti í leikskólum: Styrkir, veikleikar, menning og margbreytileiki. Í Kristín Karlsdóttir og Anna Magnea Hreinsdóttir (ritstjórar), Leikum, larum, lifum: Námssvið leikskóla og grunnpattir menntunar (bls. 155-188). Reykjavík: Rannung og Háskólaútgáfan.

Hanna Ragnarsdóttir.(2019).

„Раð er ekki til ein uppskrift.“ Fyrsta ár flóttabarna í leikskólum í premur sveitarfélögum á Íslandi.

Netla - Veftímarit um uppeldi og menntun. Menntavísindasvið Háskóla Íslands.

Sótt af http://netla.hi.is/serrit/2019/menntun_barna_leik_grunn/04.pdf

DOI: https://doi.org/10.24270/serritnetla.2019.36 